\title{
Evaluation of climate change impacts and adaptation measures for rice cultivation in Northeast Thailand
}

\author{
Mukand S. Babel ${ }^{1, *}$, Anshul Agarwal ${ }^{1}$, Dillip Kumar Swain ${ }^{2}$, Srikantha Herath ${ }^{3}$ \\ ${ }^{1}$ Water Engineering and Management, Asian Institute of Technology, PO Box 4, Klong Luang, Pathumthani 12120, Thailand \\ ${ }^{2}$ Agricultural and Food Engineering Department, Indian Institute of Technology, Kharagpur 721302, India \\ ${ }^{3}$ Environment and Sustainable Development, United Nations University, Tokyo 1508925, Japan
}

\begin{abstract}
We investigated the effects of climate change on rainfed rice yield using the CERES-rice crop growth model and identified suitable agro-adaptation measures to address the threats induced by climate change on rice production in Northeast Thailand. The crop physiological data from field experiments conducted in the region was used to calibrate the model. Future climate scenarios for the periods 2020-2029, 2050-2059 and 2080-2089 were developed using the global climate model ECHAM4 and downscaled using the regional climate model PRECIS. Results indicated a decline in the rice yield in the region by $17.81,27.59$ and $24.34 \%$ for the 2020 s, 2050s and 2080s, respectively, compared to the average yield during 1997-2006 under the ECHAM4 A2 climate change scenario. Simulation experiments suggested that for a given temperature, the yields of 2 rice varieties, KDML105 and RD6, increase with increases in $\mathrm{CO}_{2}$ concentration. On the contrary, increases in temperature reduce the yield at a constant $\mathrm{CO}_{2}$ concentration. The overall decrease in yield under future climatic conditions can be mitigated significantly by proper nutrient management and altering planting dates. Hybrid rice cultivars having a high temperature tolerance can also help to address the challenges imposed by future climate.
\end{abstract}

KEY WORDS: Agro-adaptation · CERES-rice · Climate change · ECHAM4 A2 scenario · Forecasting • Northeast Thailand $\cdot$ Rice yield

Resale or republication not permitted without written consent of the publisher

\section{INTRODUCTION}

Climate change is likely to have wide-ranging effects on the environment and on socio-economic and related sectors. The water and agriculture sectors, in particular, are likely to be significantly impacted by changing climate (IPCC 2007, Mestre-Sanchís \& Feijóo-Bello 2009, Molua 2009), as it increases pressure on land and water resources and will even cause agriculture to enter into a non-sustainable cycle of food production (Horie 2005). Moreover, various climate extreme events such as more frequent and more intense droughts, floods, cyclones and heat waves pose increasing and, often times, incalculable threats to agricultural production (Alcamo et al. 2007). Agriculture is critical for the economic growth, poverty alleviation and food security of developing countries, and thus these countries are particularly vulnerable to the ef- fects of climate change, since they lack the social, technological and financial resources to enable them to adapt to these changes (UNFCC 2007).

Food production will be faced with more challenges as agricultural crop yields are affected by changing climate due to the associated alterations in the temperature and rainfall cycles as well as changes in soil quality, pests and diseases. In fact, declining crop yield has already been observed in many Asian countries, partly due to rising temperatures and extreme weather events (Cruz et al. 2007). Nelson et al. (2009) further argued that, in developing countries, climate change will likely cause yield reduction for most staple crops, with South Asia being the most susceptible region. A decline in yield is mainly expected due to a shortening of the growth period, a decrease in photosynthesis ability and an increase in respiration, thus increasing water requirements. Rice is an important food crop for 
more than half of the world's population. Since the 1980s there has been a decline in per capita rice production and productivity in Asia; therefore, the effect of climate change is a major concern to rice production in the region, which accounts for $>80 \%$ of the world's production and consumption (FAO 2004). Due to limited development of irrigation, a significant portion of this production is contributed by rainfed areas in Asia that are particularly susceptible to climate change.

Several modeling studies revealed that an increase in $\mathrm{CO}_{2}$ and temperature will significantly alter the production of wheat (e.g. in China, Thomson et al. 2006), maize (e.g. in North Central China, Tao \& Zhang 2010) and rice (e.g. in Japan, Horie 2005; China, Erda et al. 2005; Thailand, Buddhaboon et al. 2004; Lao PDR, Inthavon et al. 2004; and India, Krishnan et al. 2007). However, studies on the impacts of future climate change on rice yield in most of the Southeast Asian countries are still very limited, especially under rainfed conditions, where earlier but less reliable forecasts may actually be more valuable than those that are more accurate but late (Sivakumar 2006). This needs particular attention, as modeling studies have projected crop yield losses even with minimal warming in the tropics (Easterling et al. 2007).

To assess the vulnerability of agriculture to climate change it is necessary to consider the role of adaptation, as appropriate adaptation can greatly reduce the magnitude of the impacts of climate change (Reidsma et al. 2010). Falloon \& Betts (2010) reviewed climate change impacts on agriculture in Europe, and emphasized the need for effective adaptation as a result of increased vulnerability of production under reduced water supply and increased flood and drought risks in Europe. Adaptation refers to the adjustment in ecological, social, or economic systems in response to actual or expected climate stimuli and their effects or impacts, specifically, the change in processes, practices and structures to moderate potential damages or to exploit beneficial opportunities associated with climate change (IPCC 2001). Without adaptation, climate change is generally problematic for agricultural production, economies and communities dependent on agriculture; however, with appropriate adaptation, vulnerabilities can be reduced, and there are numerous opportunities to be realized (Smit \& Mark 2002, Wilk \& Wittgren 2009). It should be noted, however, that the applicability and success of various adaptation options is influenced by a myriad of factors (Bryan et al. 2009) and will vary between regions and farm types; thus, to determine an adaptation option for a particular situation, one needs to assess its effectiveness, economic feasibility, flexibility and institutional compatibility.

Various rice varieties have the ability to tolerate the impacts of climate, such as high temperature, floods, droughts, etc. Thus, selection of the appropriate rice varieties under particular conditions deserves more consideration with respect to climate change (FAO 2007). Krishnan et al. (2007) performed various modeling experiments to determine the effects of climate change on rice yield, and proposed various methods of adaptation for higher rice yield under specific climate change scenarios, such as adjustments in sowing dates and in the tolerance of spikelet fertility to temperature.

Given the above background, a need exists to predict future climate regimes, the way they affect physical factors such as the $\mathrm{CO}_{2}$ concentration, surface temperature and the water cycle, and the resulting rice yields, under predicted climate scenarios. Also, to meet the global food demand and to ensure food security, there is a need to increase rice production by adapting to future climate conditions. The objectives of the present study were to assess the impacts of future climate change on rice yield in Northeast Thailand and to identify and evaluate potential management practices (i.e. agro-adaptation measures) using the CERES-rice model (DSSAT Version 4.0).

\section{STUDY AREA}

Northeast Thailand, comprising 19 provinces, lies between latitude $14.50-17.50^{\circ} \mathrm{N}$ and longitude $102.12-$ $104.90^{\circ} \mathrm{E}$. The region has about 9.3 million ha of agricultural land, of which about 7.9 million ha is under rainfed farming. Up to $75 \%$ of this land is devoted to rice, and the planting area varies considerably from year to year. Rice is the main crop; it is sown in June-July and harvested in November-December. Rice production in the region relies mainly on rainfall; irrigation is limited to about $20 \%$ of the total riceproducing area.

The region has a tropical climate, with average temperature ranging from 19.6 to $30.2^{\circ} \mathrm{C}$. OctoberFebruary is the cool season, while March-May is the hot season, with highest temperatures observed in the month of April. Rainfall in the region is highly unpredictable, mainly concentrated in the rainy season, i.e. May-October. The average annual rainfall varies from 1270 to $2000 \mathrm{~mm}$ within the region. Soils of the study area are highly acidic, saline and low in fertility. The present study used the climatic and soil data, as well as other information, from crop experiments conducted at the Rice Research Centers (RRC) in 3 provinces, namely Khon Kaen, Roi Et and Ubon Ratchathani, representing Northeast Thailand (Fig. 1).

The average rice yield in the region is $1.9 \mathrm{t} \mathrm{ha}^{-1}$, which is the lowest in the country, with the countrywide average being $2.5 \mathrm{t} \mathrm{ha}^{-1}$ (Haefele et al. 2006). Rainfed rice is grown under poor conditions, i.e. poor 


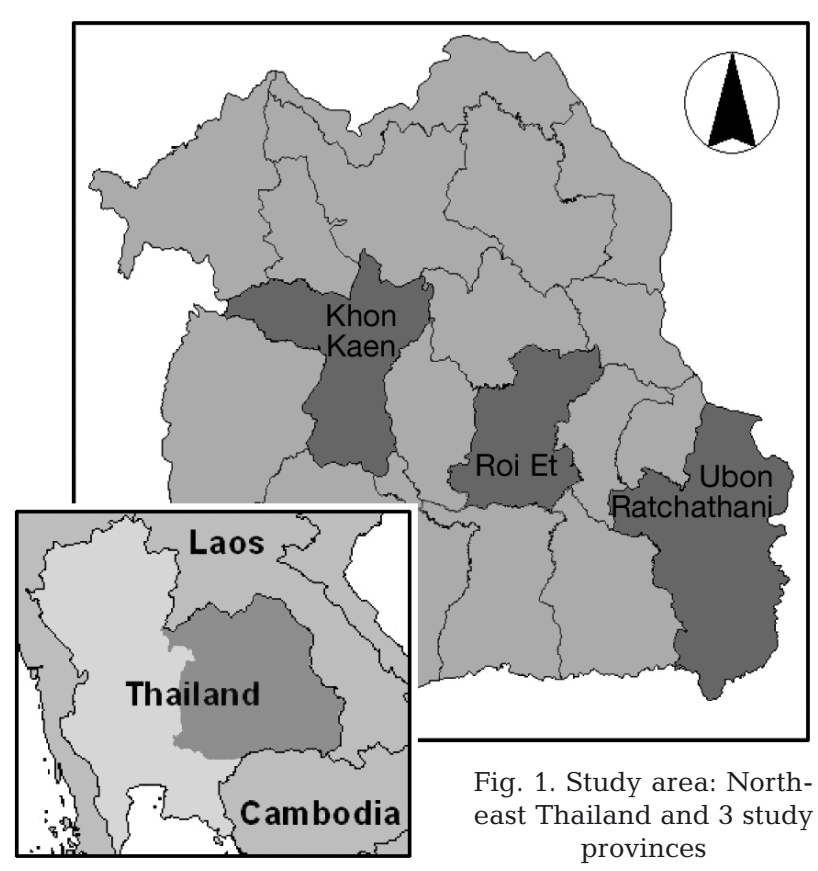

crop management with low inputs, and is highly subject to climatic variability. The major production constraints are high rainfall variability, drought, submergence and inherent low soil fertility (Kupkanchanakul 2000). The main varieties of Jasmine rice, namely KDML105 (Khao Dok Mali 105) and RD6 (Rice Department 6), are medium-maturing varieties and cover almost $80 \%$ of the rice fields in Northeast Thailand (Miyagawa 2001).

\section{MATERIALS AND METHODS}

\subsection{Data collection}

The meteorological data for the weather stations in Khon Kaen, Roi Et and Ubon Ratchathani were collected from the Thai Meteorological Department (TMD). Rainfall data were considered for the nearest rainfall stations from the experimental plots in the 3 provinces. The daily weather data, including rainfall, maximum and minimum temperature, sunshine hours, wind speed and evaporation, were collected for the period of 1980-2007.

The details of the field experiments conducted by the Rice Research Centers in Khon Kaen, Roi Et and Ubon Ratchathani were collected and used for model calibration and validation. The experiments were carried out in 2004 at farmer's field in Roi Et province using the cultivars KDML105 and RD6, and in 1996 at the Rice Research Centers in Roi Et and Ubon Ratchathani for cultivar KDML105. These experiments were conducted to test the effect of planting dates, fertilizer application, rainfed versus irrigation watering, management practices, etc., on yield and yield components. Details on 2 of the experiments conducted at the Rice Research Center in Ubon Ratchathani and used for model calibration and validation are given in Table 1.

The information on the physical and chemical properties of the soil was collected from the Land Development Department (LDD). There are 44 established soil types in Northeast Thailand. The major soil types used for rice cultivation are Roi Et, Ubon, Udon, Renu and Si Thon (LDD 2003). The data collected for soil types at the study sites include color, slope, runoff potential and drainage type, along with layered classification of soil texture, $\mathrm{pH}$, phosphorous, potassium, carbon, nitrogen and cation exchange capacity.

\subsection{Crop simulation model}

The MS Windows-based CERES-rice model (Singh et al. 1993, Ritchie et al. 1998) released with DSSAT Version 4.0 (Hoogenboom et al. 2003) in 2004 by the International Consortium for Agricultural Systems Application, University of Hawaii, USA, was used in the present study. The model is based on the understanding of plants, soil, weather and management interaction to predict growth and yield. Yield-limiting factors like water and nutrient stresses ( $\mathrm{N}$ and $\mathrm{P}$ ) are considered by the model. A suite of tools, including XBuild to create and modify experimental files, Weatherman for weather data, GBuild for graphing of outputs, ATCreate for observed data and SBuild for soil database, are available for data management and analysis (Hoogenboom et al. 2003). It is a process-based, management-oriented model that can simulate the growth and development of rice as affected by varying levels of water and nitrogen. The model can identify gaps between potential and on-station and on-farm yields.

Table 1. Crop growth characteristics and other input data for model calibration and validation, Rice Research Center, Ubon Ratchathani. NPK: relative concentrations of nitrogen, phosphorus and potassium; DAS: days after sowing

\begin{tabular}{|c|c|c|}
\hline & Calibration & Validation \\
\hline Seeding date & 8 Aug 1996 & 28 Aug 1996 \\
\hline Transplanting date & 5 Sep 1996 & 26 Sep 1996 \\
\hline Plant density $\left(\mathrm{m}^{-2}\right)$ & 27 & 27 \\
\hline Flowering date & 3 Nov 1996 & 18 Nov 1996 \\
\hline Treatment & Rainfed & Rainfed \\
\hline \multirow[t]{2}{*}{ Fertilizer application } & (Mixed NPK 16:16:8) & (Mixed NPK 16:16:8) \\
\hline & $96 \mathrm{~kg} \mathrm{ha}^{-1} 31 \mathrm{DAS}$ & $96 \mathrm{~kg} \mathrm{ha}^{-1} 31 \mathrm{DAS}$ \\
\hline
\end{tabular}


In CERES-rice the genetic coefficients, as defined by Ritchie et al. (1998), are used as model inputs to describe crop phenology in response to temperature and photoperiod. The genetic coefficients used for the growth and development of rice varieties are-P1: basic vegetative phase, the time period expressed as growing degree days (GDD) in degrees Celsius above a base temperature of $9^{\circ} \mathrm{C}$; $\mathrm{P} 2 \mathrm{O}$ : critical photoperiod or the longest day length in hours at which the development occurs at a maximum rate; P2R: photoperiod sensitivity coefficient, the extent to which the phasic development leading to panicle initiation is delayed; P5: time period in GDD from the beginning of grain filling to physiological maturity with a base temperature of $9^{\circ} \mathrm{C}_{i} \mathrm{G} 1$ : potential spikelet number per panicle; G2: single grain weight; G3: tillering coefficients relative to IR64 cultivars; and G4: temperature tolerance coefficient.

The data obtained from the field experiments conducted by the Rice Research Center in Ubon Ratchathani for crop growth characteristics, i.e. flowering day, maturity day, grain yield and harvest index, were compared with the simulated results for model calibration and validation. The model was further evaluated by using the observed and simulated weather data for 1980-1989 as an input to the calibrated model and comparing the simulated yields at the 3 locations with the observed yields.

\subsection{Climate model}

The future climate scenario used in the present study was collected from the Southeast Asia START Regional Center at Chulalongkorn University, Thailand. The future climate data were predicted using the global climate model (GCM) ECHAM4 (ECMWF atmospheric general circulation model coupled with the University of Hamburg's ocean circulation model) developed for the global resolution of $280 \times 280 \mathrm{~km}$ by the Max Planck Institute, Germany. These data were developed considering world growth forced by a level of atmospheric $\mathrm{CO}_{2}$ according to the IPCC SRES A2 scenario, one of the most pessimistic projections. These data were further downscaled at the regional level using the regional climate model (RCM) PRECIS (providing regional climates for impact studies) for the study area at $25 \times 25 \mathrm{~km}$. The downscaled data for the periods of 2020-2029, 2050-2059 and 2080-2089 for the grid that falls nearest to the study locations in the 3 provinces were used.

The predicted future climate scenario was applied to the calibrated CERES-rice model for the study sites to determine the impacts on rice yield during the 3 future periods. The impacts were then determined by com- puting the changes in the yield averaged for each of the 3 future decades (2020-2029, 2050-2059 and 2080-2089), with respect to the yield as obtained for the actual daily weather data collected for 10 consecutive years from 1997 to 2006 for each of the 3 sites.

\subsection{Agro-adaptation measures}

Various possible agro-adaptation measures, including alternate sowing dates, water management, different tillage practices, nutrient management, improved heat-resistant varieties, etc., were applied to the calibrated CERES-rice model. The impacts of the adaptation measures on crop yield were determined for the future climate predicted by GCM ECHAM4 A2 at Khon Kaen, Roi Et and Ubon Ratchathani. Several alternate sowing dates from -30 to $+30 \mathrm{~d}$, with an interval of $10 \mathrm{~d}$ with respect to the current sowing date, were considered. Different rates of nitrogen fertilizer (mixed NPK fertilizer of type 16-16-8), i.e. 0.50-, 1.25-, 1.50- and 2.00-fold the initial rate at the study sites, were applied to evaluate the impact on rice yield; alternate times of fertilizer application were also analyzed. The different methods and depths of tillage were also considered to determine the effect on yield. The suitability of hybrid rice cultivars, such as Suphanburi60, Chainat1, DOA1 and Pitsanuloke2, which have higher yield potentials, was determined considering the same management practices applied to present cultivars. The effect on the average yield and standard deviation for a decade was compared with the yield in that period under normal conditions. The change in the yield compared to the yield under conditions similar to the base period was examined to determine the effectiveness of adaptation measures that may mitigate the negative effects of climate change.

\section{RESULTS AND DISCUSSION}

\subsection{Simulated and observed weather data}

The monthly total rainfall and monthly mean, maximum and minimum temperatures averaged for the base period 1980-1989 were used to check the consistency of the simulated data for the 3 provinces. The cumulative rainfall with observed and simulated weather data for Ubon Ratchathani was in close agreement, as shown in Fig. 2, with an average value of $1596 \pm 239 \mathrm{~mm}$ for observed and $1591 \pm 131 \mathrm{~mm}$ for simulated rainfall. The good agreement is also reflected in the root mean square error (RMSE) value of $58.30 \mathrm{~mm}$ and the coefficient of determination $\left(\mathrm{r}^{2}\right)$ of 0.79 . Similarly, the cumulative rainfall values with simulated and observed 
weather data for Khon Kaen of $1118 \pm 123$ and $1179 \pm$ $167 \mathrm{~mm}$, respectively, are in good agreement, with a RMSE value $69.30 \mathrm{~mm}$ and a coefficient of determination 0.59, and, for Roi Et, the corresponding values of $1364 \pm 91$ and $1381 \pm 131 \mathrm{~mm}$ are also in good agreement, with a RMSE value $66.90 \mathrm{~mm}$ and $\mathrm{a} \mathrm{r}^{2}$ value 0.68 .

The difference between maximum and minimum temperature values at Ubon Ratchathani for observed weather $\left(32.61 \pm 0.31\right.$ and $21.67 \pm 0.45^{\circ} \mathrm{C}$, respectively) was almost $2^{\circ} \mathrm{C}$ higher than for simulated weather $\left(32.37 \pm 0.27\right.$ and $\left.23.73 \pm 0.50^{\circ} \mathrm{C}\right)$. The monthly average maximum and minimum temperatures shown in Fig. 3 have $\mathrm{r}^{2}$ values of 0.61 and 0.78 , respectively, and RMSE values of 1.62 and $2.13^{\circ} \mathrm{C}$, respectively. Similarly, for Khon Kaen province the difference between maximum and minimum temperatures of observed $(32.67 \pm 2.08$ and $\left.22.03 \pm 3.32^{\circ} \mathrm{C}\right)$ and simulated $(32.80 \pm 3.49$ and $23.42 \pm 3.15^{\circ} \mathrm{C}$ ) weather was almost $1^{\circ} \mathrm{C}$ higher. The monthly average maximum and minimum temperatures have RMSE values of 2.19 and $1.94^{\circ} \mathrm{C}$ and $\mathrm{r}^{2}$ values of 0.60 and 0.82 , respectively. For Roi Et, the difference between maximum and minimum temperature of observed $\left(31.98 \pm 2.15\right.$ and $\left.22.25 \pm 3.28^{\circ} \mathrm{C}\right)$ and simulated $\left(32.23 \pm 1.97\right.$ and $\left.23.75 \pm 2.92^{\circ} \mathrm{C}\right)$ weather was also almost $1{ }^{\circ} \mathrm{C}$ higher. The monthly average maximum and minimum temperatures have RMSE values of 1.17 and $2.23^{\circ} \mathrm{C}$ and $r^{2}$ values of 0.70 and 0.72 , respectively.

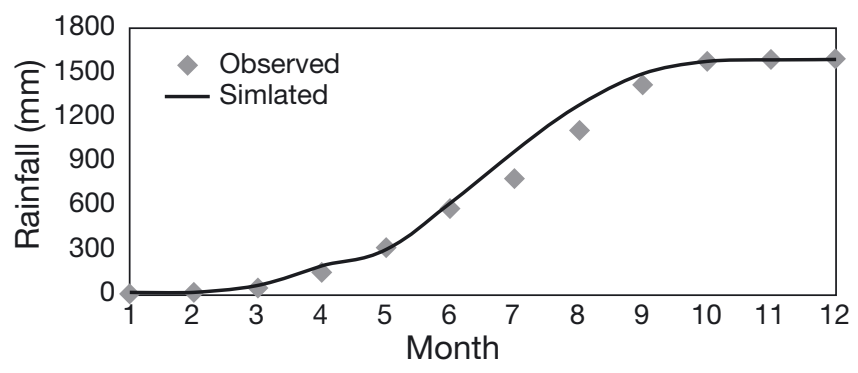

Fig. 2. Observed and simulated cumulative monthly rainfall for 1980-1989 at Ubon Ratchathani

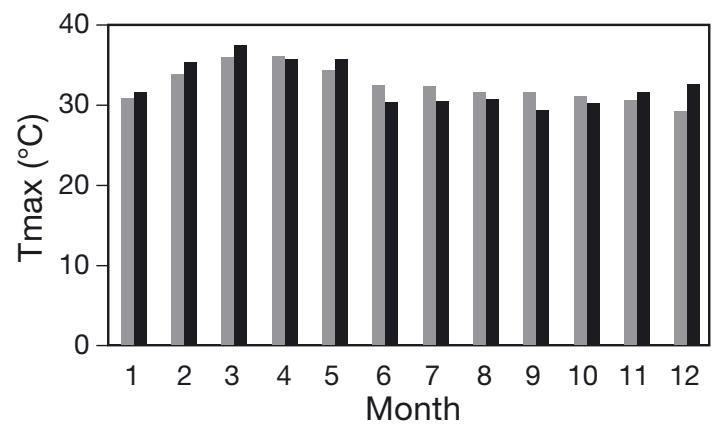

\subsection{Model calibration and validation}

The observed and simulated yield components at Ubon Ratchathani, as presented in Table 2, clearly indicated that the model results are in agreement with the field observations. Results are presented for 2 cases, seeding on the normal date (8 August 1996) and seeding at a later date (28 August 1996), as mentioned in Table 1 . The late seeding means that the seeding was delayed by $20 \mathrm{~d}$. The yield components simulated by the model indicated an error of $0.48 \%$ in grain yield and $3.50 \%$ in harvest index for seeding at a normal date. For the case of late seeding, the errors in simulated grain yield and harvest index were 3.13 and $5.26 \%$, respectively. The increased error in late seeding may be due to climatic and other factors affecting the grain yield and by-product harvest in field experiments resulting in reduced observed values compared to simulated values of these 2 parameters. However, the errors are still acceptable. Similarly, although results are not presented here, the model performance was also evaluated using the experimental data and results from the Rice Research Centers in Khon Kaen and Roi Et. The genotype coefficients for the cultivars KDML105 and RD6, as reported by Buddhaboon et al. (2004) and given in Table 3, were used for the study.

\subsection{Future climate scenario}

The $\mathrm{CO}_{2}$ concentrations and the changes in average maximum and minimum temperatures and rainfall at Khon Kaen, Roi Et and Ubon Ratchathani for the future periods 2020-2029, 2050-2059 and 2080-2089 relative to the baseline period of 1980-1989 are provided in Table 4 . The average $\mathrm{CO}_{2}$ concentration during the 1980-1989 period was $330 \mathrm{ppm}$. Results indicated that there will be an increase in maximum and minimum temperatures, as well as in rainfall, at all 3 locations. At Ubon Ratchathani, the increase in maximum temperature could be as high as $3.51^{\circ} \mathrm{C}$ for $2080-2089$ and the

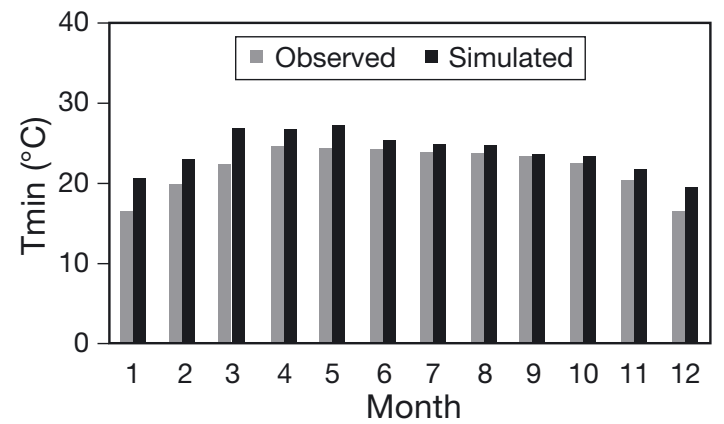

Fig. 3. Observed and simulated monthly maximum $\left(T_{\max }\right)$ and minimum $\left(T_{\min }\right)$ temperatures averaged for 1980-1989 at Ubon Ratchathani 
Table 2. Observed and simulated yield components of cultivar KDML105 in 1996 at Rice Research Center, Ubon Ratchathani

\begin{tabular}{|c|c|c|c|c|c|c|}
\hline & \multirow{2}{*}{ Simulated } & \multicolumn{2}{|c|}{ - Calibration } & \multirow[b]{2}{*}{ Simulated } & —Validation & \multirow[b]{2}{*}{ Percent errol } \\
\hline & & Observed & Percent error & & Observed & \\
\hline Anthesis day (day after planting) & 80 & 87 & -8.05 & 68 & 73 & -6.85 \\
\hline By-product harvest $\left(\mathrm{kg} \mathrm{ha}^{-1}\right)$ & 4786 & 4800 & -0.29 & 4206 & 4405 & -4.52 \\
\hline Grain yield $\left(\mathrm{kg} \mathrm{ha}^{-1}\right)$ & 3376 & 3360 & 0.48 & 2805 & 2720 & 3.13 \\
\hline Harvest index & 0.41 & 0.40 & 3.50 & 0.40 & 0.38 & 5.26 \\
\hline
\end{tabular}

Table 3. Genetic coefficients of rice cultivars, KDML105 and RD6. Data source: Buddhaboon et al. (2004)

\begin{tabular}{|lcccccccc|}
\hline \multirow{2}{*}{ Rice cultivar } & \multicolumn{1}{c|}{ Genetic coefficients } & \multirow{2}{*}{ P2 } & \multirow{2}{*}{ G3 } & \multirow{2}{*}{ G4 } \\
\cline { 2 - 8 } & \multirow{2}{*}{ P1 } & P5 & P2R & P2O & G1 & G & \\
\hline KDML105 & 502.30 & 386.50 & 1233.00 & 12.70 & 45.70 & 0.027 & 1 & 0.95 \\
RD6 & 550.30 & 386.50 & 1243.00 & 12.80 & 48.70 & 0.028 & 1 & 0.95 \\
\hline
\end{tabular}

increase in rainfall could be $45.20 \%$ for $2050-2059$ relative to the base period (1980-1989).

\subsection{Rice yield for the baseline period weather}

The simulated rice yields for the baseline period 1980-1989 were in good agreement at all 3 provinces for the observed and simulated weather data, as shown in Fig. 4. The rice yields of $3186 \pm 220,3081 \pm 284$ and $2908 \pm 493 \mathrm{~kg} \mathrm{ha}^{-1}$, simulated by CERES-rice and averaged for the decade with observed weather data, are comparable with the yields of $3022 \pm 351,2948 \pm 196$ and $2640 \pm 503 \mathrm{~kg} \mathrm{ha}^{-1}$ for the ECHAM4 A2-simulated weather data at Khon Kaen, Roi Et and Ubon Ratchathani, respectively.

\subsection{Yield and its components for observed and future periods}

The simulated yields and yield components for the cultivar KDML105 for observed and future climate periods under the ECHAM4 A2 SRES scenario at Ubon Ratchathani are given in Table 5. Although the num- ber of panicles per unit area remained almost the same (varying from 27.30 to 36.20 no. $\mathrm{m}^{-2}$, i.e. a reduction of about $18 \%$ for 2050-2059 and an increase of about 9\% for 2080-2089 compared to 1997-2006), the total number of grains per unit area was considerably reduced, with a maximum reduction of $35 \%$ for 2080-2089 compared to 1997-2006. This reduction was caused by the rise in temperature, which decreased the grain-filling duration from 32 to $28 \mathrm{~d}$. The duration between anthesis and maturity was reduced for future periods, which would affect spikelet sterility and, hence, reduce the final grain yield. The harvest index was also reduced for future periods (from 0.43 in 1997-2006 to 0.28 in 2080-2089), indicating that, although the total biomass yield remained almost the same (varying from 6353 to $6742 \mathrm{~kg} \mathrm{ha}^{-1}$ ), the grain yield was reduced significantly from $2732 \mathrm{~kg} \mathrm{ha}^{-1}$ in $1997-2006$ to $1855 \mathrm{~kg} \mathrm{ha}^{-1}$ in 2080-2089, a reduction of almost 35\%. Similar trends in yield and yield components were obtained at Khon Kaen and Roi Et.

\subsection{Effect of predicted GCM scenario on rice yield}

The simulated KDML105 rice yields for the observed weather (1997-2006) and predicted weather for the 2020s, 2050s and 2080s and the changes in yields are given in Table 6. There was a significant decline in the yield for future periods. By taking the average of the 3 locations to represent Northeast Thailand, a decline in rice yield of $17.81,27.59$ and $24.34 \%$ in the $2020 \mathrm{~s}$,

Table 4. Average increases in $\mathrm{CO}_{2}, T_{\max }, T_{\min }$ and percent increases in annual rainfall for future periods relative to the base period of 1980-1989

\begin{tabular}{|c|c|c|c|c|c|c|c|c|c|c|}
\hline \multirow[t]{2}{*}{ Time period } & \multirow{2}{*}{$\begin{array}{c}\mathrm{CO}_{2} \text { conc. } \\
(\mathrm{ppm})\end{array}$} & \multicolumn{3}{|c|}{ Khon Kaen } & \multicolumn{3}{|c|}{ Roi Et } & \multicolumn{3}{|c|}{ Ubon Ratchathani } \\
\hline & & $\begin{array}{l}T_{\max } \\
\left({ }^{\circ} \mathrm{C}\right)\end{array}$ & $\begin{array}{l}T_{\min } \\
\left({ }^{\circ} \mathrm{C}\right)\end{array}$ & $\begin{array}{c}\text { Rainfall } \\
(\%)\end{array}$ & $\begin{array}{l}T_{\max } \\
\left({ }^{\circ} \mathrm{C}\right)\end{array}$ & $\begin{array}{l}T_{\min } \\
\left({ }^{\circ} \mathrm{C}\right)\end{array}$ & $\begin{array}{c}\text { Rainfall } \\
(\%)\end{array}$ & $\begin{array}{l}T_{\max } \\
\left({ }^{\circ} \mathrm{C}\right)\end{array}$ & $\begin{array}{l}T_{\min } \\
\left({ }^{\circ} \mathrm{C}\right)\end{array}$ & $\begin{array}{c}\text { Rainfall } \\
(\%)\end{array}$ \\
\hline $2020-2029$ & 437 & 0.32 & 2.14 & 5.90 & 0.35 & 2.21 & 19.20 & 1.47 & 0.93 & 10.10 \\
\hline $2050-2059$ & 555 & 3.30 & 3.15 & 2.60 & 1.59 & 3.20 & 40.50 & 1.72 & 2.14 & 45.20 \\
\hline 2080-2089 & 735 & 3.25 & 5.19 & 5.20 & 3.20 & 5.10 & 20.10 & 3.51 & 3.06 & 2.98 \\
\hline
\end{tabular}




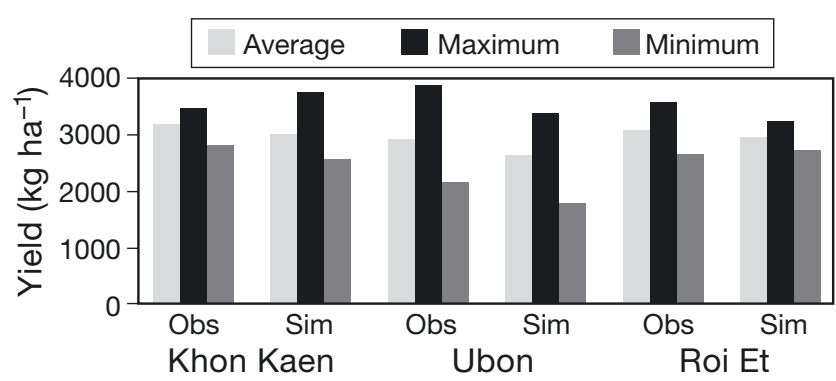

Fig. 4. Simulated rice yields with the observed and simulated weather for 1980-1989

2050s and 2080s, respectively, was expected in the region. Erda et al. (2005) found a change of -12.90 , -13.60 and $-28.60 \%$ in rainfed rice yield in China for the 2020s, 2050s and 2080s under the SRES A2 scenario. Similarly, Krishnan et al. (2007) predicted a change of $-7.63,-9.38$ and $-15.86 \%$ in the rice yield for the GFDL, GISS and UKMO scenarios using the ORYZA crop simulation model and a change of -9.02, -11.30 and $-21.35 \%$ using the INFOCROP crop simulation model for the future periods.

\subsection{Effect of temperature and $\mathrm{CO}_{2}$ levels on rice yield}

Experiments were conducted using the calibrated CERES-rice model to determine the effect of increase in $\mathrm{CO}_{2}$ and temperature on rice yield. The other weather parameters, i.e. rainfall and solar radiation, were considered the same as for the base period (1997-2006) weather. For the $\mathrm{CO}_{2}$ levels tested (330, $400,500,600,700 \mathrm{ppm})$ CERES-rice predicted an increase in yield for both cultivars KDML105 and RD6 with increasing $\mathrm{CO}_{2}$ concentration. In contrast, at all $\mathrm{CO}_{2}$ concentrations, the model predicted a decline in yield with increase in temperature. At the base $\mathrm{CO}_{2}$ concentration (330 ppm), the model predicted a decline in yield of $33.89 \%$ for KDML105 and 19.83\% for $\mathrm{RD} 6$, with a $5^{\circ} \mathrm{C}$ increase in temperature. This loss in yield may be caused by heat-induced spikelet sterility or increased crop respiration loss during grain filling, which reduces the grain-filling capacity and thus reduces the grain yield (Wassmann 2007).

At ambient temperature, for change in $\mathrm{CO}_{2}$ concentration from 330 to $700 \mathrm{ppm}$, the model predicted an increase in average yield of $16.91 \%$ for KDML105 and $30.89 \%$ for RD6. The advantage of elevated $\mathrm{CO}_{2}$ on rice yield is nullified by the rise in temperature effects. The effects of different combinations of $\mathrm{CO}_{2}$ concentrations and temperatures for the cultivar KDML105 are provided in Table 7 . There were declines in yield to varying degrees for every $1^{\circ} \mathrm{C}$ rise in temperature; in contrast, with an increase in $\mathrm{CO}_{2}$ concentration, yields increased to varying degrees. Similar trends in rice yield have been reported by Krishnan et al. (2007) for Indian conditions using the INFOCROP and ORYZA crop simulation models; ORYZA predicted a mean change of $-7.20 \%$ in yield for every $1^{\circ} \mathrm{C}$ increase in temperature, while INFOCROP predicted $-6.70 \%$. An increase in $\mathrm{CO}_{2}$ concentration (700 ppm) resulted in an increase of 30.40 and $56.40 \%$ in yield by ORYZA and INFOCROP, respectively. At higher $\mathrm{CO}_{2}$ concentrations, biomass accumulation and tillering increased, which subsequently enhanced the grain yield; however, at higher temperatures, maturity duration was reduced, the number of panicles per plant increased and the number of seeds per panicle declined sharply (Baker et al. 1992).

Table 5. Simulated yield and yield components of KDML105 at Ubon Ratchathani

\begin{tabular}{|lcccccrc|}
\hline Period & $\begin{array}{c}\text { Yield } \\
\left(\mathrm{kg} \mathrm{ha}^{-1}\right)\end{array}$ & $\begin{array}{c}\text { Panicle } \\
\left(\text { no. m }{ }^{-2}\right)\end{array}$ & $\begin{array}{c}\text { Grains } \\
\left(\text { no. m }{ }^{-2}\right)\end{array}$ & $\begin{array}{c}\text { Total biomass } \\
\left(\mathrm{kg} \mathrm{ha}^{-1}\right)\end{array}$ & $\begin{array}{c}\text { Anthesis duration } \\
(\mathrm{d})\end{array}$ & $\begin{array}{c}\text { Maturity duration } \\
(\mathrm{d})\end{array}$ & $\begin{array}{c}\text { Harvest } \\
\text { index }\end{array}$ \\
\hline $1997-2006$ & 2732 & 33.40 & 10613 & 6353 & 81 & 110 & 0.43 \\
$2020-2029$ & 2427 & 31.70 & 8990 & 6742 & 87 & 113 & 0.36 \\
$2050-2059$ & 2200 & 27.30 & 8149 & 6463 & 96 & 120 & 0.30 \\
$2080-2089$ & 1855 & 36.20 & 6869 & 6625 & 85 & 107 \\
\hline
\end{tabular}

Table 6. Simulated KDML105 rice yield and changes for 3 future periods

\begin{tabular}{|c|c|c|c|c|c|c|c|}
\hline \multirow[t]{2}{*}{ Location } & \multirow{2}{*}{$\begin{array}{c}1997-2006 \text { yield } \\
\left(\mathrm{kg} \mathrm{ha}^{-1}\right)\end{array}$} & \multicolumn{2}{|c|}{$-2020-2029$} & \multicolumn{2}{|c|}{$-2050-2059-$} & \multicolumn{2}{|c|}{$-2080-2089 \square$} \\
\hline & & Yield $\left(\mathrm{kg} \mathrm{ha}^{-1}\right)$ & Change (\%) & Yield $\left(\mathrm{kg} \mathrm{ha}^{-1}\right)$ & Change $(\%)$ & Yield $\left(\mathrm{kg} \mathrm{ha}^{-1}\right)$ & Change (\%) \\
\hline Khon Kaen & 2807 & 2101 & -25.15 & 1883 & -32.91 & 1901 & -32.27 \\
\hline Roi Et & 2128 & 1764 & -17.11 & 1481 & -32.11 & 1944 & -8.64 \\
\hline Ubon Ratchathani & 2732 & 2427 & -11.16 & 2200 & -19.47 & 1855 & -32.10 \\
\hline Average & 2556 & 2097 & -17.81 & 1855 & -27.59 & 1900 & -24.34 \\
\hline
\end{tabular}




\subsection{Adaptation measures}

Alternate crop management practices, including different sowing dates, rates of nitrogen fertilizers, time of application of nitrogen fertilizer and different depths of tillage operation were investigated at the 3 study sites as adaptation measures to mitigate the effects of climate change on rice yield. However, the effects of these measures on grain yields are described for only 1 study site, i.e. Roi Et.

\subsubsection{Sowing date}

Different studies have suggested that adjusting the sowing dates and determining the optimal dates will be helpful in reducing the effect of climate change (Kupkanchanakul 2000, Krishnan et al. 2007). To determine the optimal planting date with respect to potential yield, the planting date was gradually shifted at intervals of $10 \mathrm{~d}$ from $30 \mathrm{~d}$ before $(-30 \mathrm{~d})$ to $30 \mathrm{~d}$ after $(+30 \mathrm{~d})$ the current sowing date. The rice yield was calculated, and the percentage change in yield compared to the yield for the initial sowing date is shown in Fig. 5. For the cultivar KDML105 at Roi Et, delaying the sowing by $30 \mathrm{~d}$ from the initial sowing date of 20 June showed a significant increase of 34 and $23 \%$ in yield during the 2020s and 2050s, respectively, while delaying the sowing by $20 \mathrm{~d}$ was considered to be most significant for the 2080s. Weather analysis showed that a delay in sowing avoids high temperatures during the grain-filling phase. However, any further delay reduced the water availability and led to a decline in yield.

\subsubsection{Nitrogen application}

In the low fertile soils of Northeast Thailand nutrient management is a very important management practice. Under present conditions, fertilizers are used in

Table 7. Mean predicted change (\%) in the potential yield of KDML105 for different temperature and $\mathrm{CO}_{2}$ scenarios. Note: changes are averaged across all sites for the period $1997-2006$

\begin{tabular}{|c|c|c|c|c|c|c|}
\hline \multirow{2}{*}{$\begin{array}{l}\mathrm{CO}_{2} \\
(\mathrm{ppm})\end{array}$} & \multicolumn{6}{|c|}{ - Temperature increment $\left({ }^{\circ} \mathrm{C}\right)$} \\
\hline & 0 & 1 & 2 & 3 & 4 & 5 \\
\hline 330 & 0.00 & -5.05 & -11.53 & -15.48 & -24.45 & -33.89 \\
\hline 400 & 4.06 & -1.24 & -6.66 & -13.14 & -20.02 & -29.10 \\
\hline 500 & 9.48 & 3.07 & -0.44 & -7.80 & -16.33 & -23.65 \\
\hline 600 & 13.03 & 7.83 & 2.93 & -3.29 & -11.93 & -20.68 \\
\hline 700 & 16.91 & 12.01 & 6.26 & 0.77 & -8.27 & -17.75 \\
\hline
\end{tabular}

almost $86 \%$ of the total area where rice is cultivated. Different rates of $\mathrm{N}$ applied at Roi Et showed that an increase in the application rate of $\mathrm{N}$ increases the yield for all future periods (Fig. 6).

Along with the amount, the time of application of $\mathrm{N}$ fertilizer also affected yield, as shown in Fig. 7. Advancing the application time by $10 \mathrm{~d}$ (indicated as '-10 d' in Fig. 7) led to an increase in yield at Roi Et. For the efficient use of nitrogen in rainfed agriculture, suitable rainfall is required during $\mathrm{N}$ application. Nitrogen is one of the major causes of greenhouse gas (GHG) emission from rice fields in the form of $\mathrm{N}_{2} \mathrm{O}$, so it is very important to increase the efficiency of nitrogen use in order to reduce the associated GHG emissions. The results of the present study showed that the site-specific nutrient management system developed by the International Rice Research Institute will be very beneficial in increasing the nitrogen-use efficiency for future periods under ECHAM4 A2 climate scenarios (Wassmann \& Dobermann 2006).

\subsubsection{Tillage practices}

The effect of change in common tillage practices, i.e. ploughing and harrowing, on grain yield was analyzed as a possible adaptation practice for future weather conditions. The model simulated that the change in depth, implement and time of operation for both ploughing and harrowing does not lead to any significant improvement in grain yield.

\subsubsection{Cultivars}

Developing rice cultivars that can maintain spikelet development at high temperature and can tolerate water submergence, as well as water stress, will help to mitigate the climate risk on rice yield under future scenarios (Wassmann 2007). The genetic coefficients of

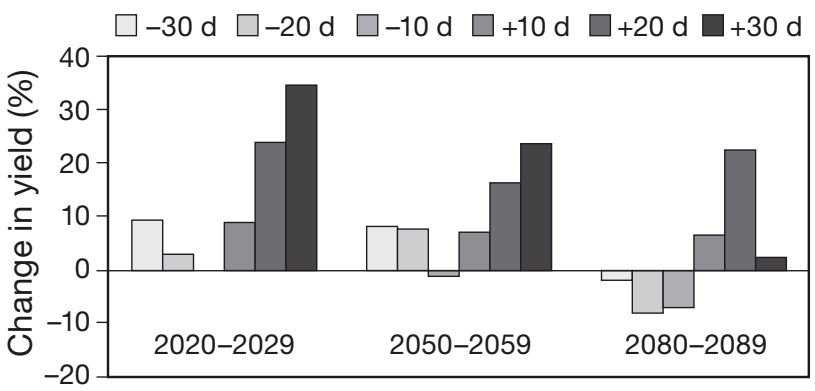

Fig. 5. Change in yield with different sowing dates for cultivar KDML105 at Roi Et 
various rice cultivars, i.e. Suphanburi60, Chainat1, Pisanuloke2, DOA1, etc., grown in Northeast Thailand are given in Table 8 . The yield was simulated using CERES-rice for conditions similar to those used for the cultivar KDML105. The cultivars Suphanburi60 and Chainat1 showed higher yield potential than KDML105 for present and future periods for the climate scenario investigated in all 3 provinces, while the cultivars DOA1 and Pisanuloke2 showed a higher yield potential at Roi Et only. From genetic coefficients of these varieties (see Table 8), it was possible to determine that Suphanburi60 and Chainat1 have longer maturity durations and lower photoperiod sensitivity

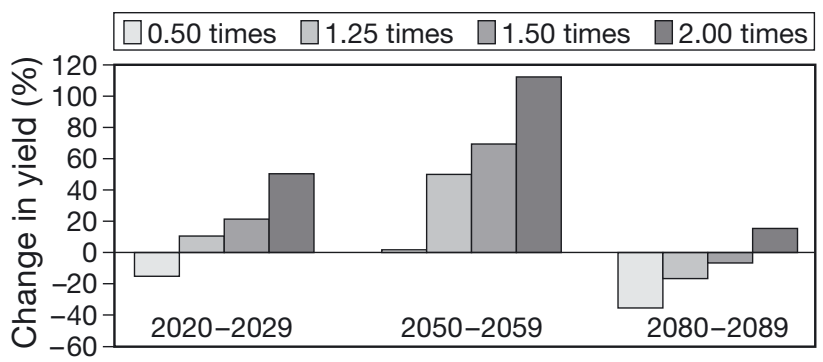

Fig. 6. Effect of the application rate of nitrogen fertilizer on yield for cultivar KDML105 at Roi Et

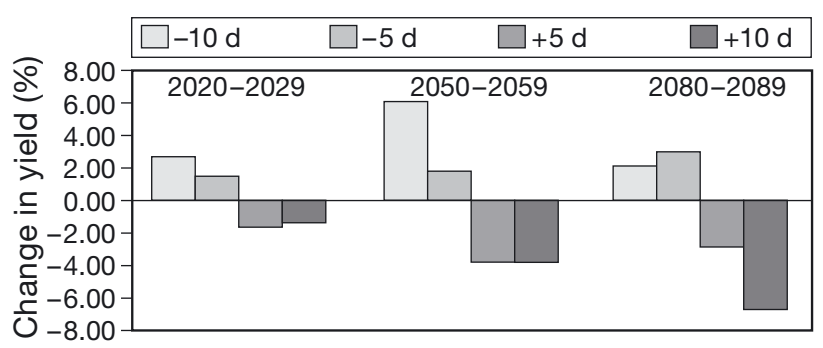

Fig. 7. Effect of the application time of nitrogen fertilizer on yield for cultivar KDML105 at Roi Et

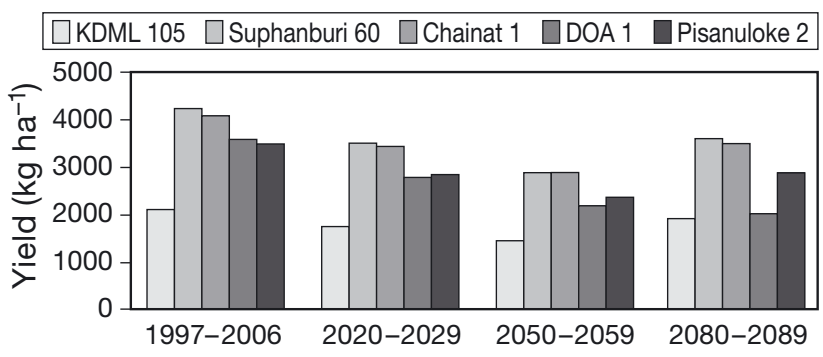

Fig. 8. Yield of rice cultivars for future periods at Roi Et coefficients. Also, the potential spikelet numbers and temperature tolerance coefficients for these varieties were higher than those for the varieties KDML105 and RD6. The model simulated a yield of 2951, 2676 and $3073 \mathrm{~kg} \mathrm{ha}^{-1}$ for Suphanburi60 and 2605, 2217 and $2536 \mathrm{~kg} \mathrm{ha}^{-1}$ for Chainat1 compared to a yield of 2102, 1883 and $1901 \mathrm{~kg} \mathrm{ha}^{-1}$ for KDML105 in the 2020s, 2050s and 2080s, respectively, in Khon Kaen. The model also simulated a high yield potential for these varieties in Ubon Ratchathani and Roi Et. The yields of these varieties at Roi Et, along with the yield of KDML105, are shown in Fig. 8.

\section{CONCLUSIONS}

The present study investigated the effects of climate change on rice production in Northeast Thailand using the CERES-rice crop growth model. The simulated weather data downscaled using RCM PRECIS was in good agreement with the observed weather in terms of seasonal pattern, indicating that PRECIS provided acceptable weather data for future periods. The $\mathrm{CO}_{2}$ concentration, temperature and rainfall were projected to increase in the future at the study area. Together these changes will adversely affect future rice yield. Furthermore, the vulnerability of rainfed rice production to climate variability and changes will lead to further large annual fluctuations in yield in the study area. The suitable adaptive measures and policies to counteract the impacts of future climate change on rice yield in the study area, where rice is mainly grown as a subsistence crop for the local population, will help to ensure global food security.

Acknowledgments. The authors acknowledge the financial support provided by the United Nations University to fund the field work conducted by A.A. as part of his master's degree at the Asian Institute of Technology, Pathumthani, Thailand. The authors thank Mr. Aldrin Rivas for his improvement of the manuscript. 


\section{LITERATURE CITED}

Alcamo J, Dronin N, Endejan M, Golubev G, Kirilenko A (2007) A new assessment of climate change impacts on food production shortfalls and water availability in Russia. Glob Environ Change 17:429-444

Baker JT, Allen AH, Boote KJ (1992) Temperature effect on rice at elevated $\mathrm{CO}_{2}$ concentration. J Exp Bot 43:959-964

Bryan E, Deressa TT, Gbetibouo GA, Ringler C (2009) Adaptation to climate change in Ethiopia and South Africa: options and constraints. Environ Sci Policy 12:413-426

Buddhaboon C, Kongton S, Jintrawet A (2004) Climate scenario verification and impact on rainfed rice production. Report of APN CAPABLE Project, Southeast Asia START Regional Center, Chulalongkorn University, Bangkok

Cruz RV, Harasawa H, Lal M, Wu S and others (2007) Asia. In: Parry ML, Canziani OF, Palutikof JP, van der Linden PJ, Hanson CE (eds) Climate change 2007: impacts, adaptation and vulnerability. Contribution of Working Group II to the 4th assessment report of the Intergovernmental Panel on Climate Change, Cambridge University Press, Cambridge, p 469-506

Easterling WE, Aggarwal PK, Batima P, Brander KM and others (2007) Food, fibre and forest products. In: Parry ML, Canziani OF, Palutikof JP, van der Linden PJ, Hanson CE (eds) Climate change 2007: impacts, adaptation and vulnerability. Contribution of Working Group II to the 4th assessment report of the Intergovernmental Panel on Climate Change. Cambridge University Press, Cambridge, p 273-313

Erda L, Wei X, Hui J, Yinlong X, Yue L, Liping B, Liyong X (2005) Climate change impacts on crop yield and quality with $\mathrm{CO}_{2}$ fertilization in China. Philos Trans R Soc B 2005: 2149-2154

Falloon P, Betts R (2010) Climate impacts on European agriculture and water management in the context of adaptation and mitigation - the importance of an integrated approach. Sci Total Environ 408:5667-5687

FAO (Food and Agriculture Organization) (2004) Agriculture 21. International Rice Commission. Available at: www. fao.org/ag/AGP/AGPC/doc/field/commrice/welcome.html (accessed on 24 October 2010)

FAO (Food and Agriculture Organization) (2007) Adaptation to climate change in agriculture, forestry and fisheries: perspective, framework and priorities. Interdepartmental working group on climate change. FAO, Rome

Haefele SM, Naklang K, Harnpichitvitaya D, Jearakongman S and others (2006) Factors affecting rice yield and fertilizer response in rainfed lowlands of Northeast Thailand. Field Crops Res 98:39-51

Hoogenboom G, Jones JW, Porter CH, Wilkens PW and others (eds) (2003) Decision support system for agrotechnology transfer, Version 4.0. Volume 1: Overview. University of Hawaii, Honolulu, HI

Horie T (2005) Climate change and food security with special attention to rice. In: Proc Global Environ Action (GEA) Conf for sustainable future '05. Tokyo, www.gea.or.jp/41activ7/ confe05/horie-paper.pdf (accessed 12 November 2010)

Inthavon T, Jintrawet A, Chinvanno S, Snidvongs A (2004) Impact of climate change on rainfed lowland rice production in Savannakhet Province, Lao PDR. Report of APN CAPABLE Project, Southeast Asia START Regional Center, Chulalongkorn University, Bangkok

IPCC (Intergovernmental Panel on Climate Change) (2001) Climate change 2001: impacts, adaptation and vulnerability. Report of Working Group II. Cambridge University Press, Cambridge

IPCC (Intergovernmental Panel on Climate Change) (2007)

Editorial responsibility: Gerrit Hoogenboom,

Prosser, Washington, USA
Climate change 2007: impacts, adaptation and vulnerability. Contribution of Working Group II to the 4th assessment report of the intergovernmental panel on climate change. Cambridge University Press, Cambridge

Krishnan P, Swain DK, Bhaskar BC, Nayak SK, Dash RN (2007) Impact of elevated $\mathrm{CO}_{2}$ and temperature on rice yield and methods of adaptation as evaluated by crop simulation studies. Agric Ecosyst Environ 122:233-242

Kupkanchanakul T (2000) Bridging the rice yield gap in Thailand. In: Papademetriou MK, Dent FJ, Herath EM (eds) Bridging the rice yield gap in Asia and the Pacific. RAP Publication, Bangkok, p 146-156

LDD (Land Development Department) (2003) Characterization of established soil series in the northeast region of Thailand. Reclassified according to soil taxonomy 2003. LDD, Bangkok

> Mestre-Sanchís F, Feijóo-Bello ML (2009) Climate change and its marginalizing effect on agriculture. Ecol Econ 68: 896-904

Miyagawa S (2001) Dynamics of rainfed lowland rice varieties in north-east Thailand. Available at: www.unu.edu/env/ plec/marginal/proceedings/MiyagawaCH5.pdf (accessed on 24 October 2010)

- Molua EL (2009) An empirical assessment of the impact of climate change on smallholder agriculture in Cameroon. Global Planet Change 67:205-208

Nelson GC, Rosegrant MW, Koo J, Robertson R and others (2009) Climate change: impact on agriculture and costs of adaptation. International Food Policy Research Institute, Washington, DC

Reidsma P, Ewert F, Lansink AO, Leemans R (2010) Adaptation to climate change and climate variability in European agriculture: the importance of farm level responses. Eur J Agron 32:91-102

Ritchie JT, Singh U, Godwin DC, Bowen WT (1998) Cereal growth, development and yield. In: Tsuji GY, Hoogenboom G, Thornton PK (eds) Understanding options for agricultural production. Kluwer, Dordrecht, p 79-98

Singh U, Ritchie JT, Godwin DC (1993) A users' guide to CERES-rice simulation manual, V 2.10. IFDC-SM-4, IFDC, Muscle Shoals, AL

Sivakumar MVK (2006) Climate predictions and agriculture: current status and future challenges. Clim Res 33:3-17

Smit B, Mark WS (2002) Adaptation options in agriculture to climate change: a typology. Department of Geography, University of Guelph, Guelph

Tao F, Zhang Z (2010) Adaptation of maize production to climate change in North China Plain: quantify the relative contributions of adaptation options. Eur J Agron 33:103-116

- Thomson AM, Izaurralde RC, Rosenberg NJ, He X (2006) Climate change impacts on agriculture and soil carbon sequestration potential in the Huang-Hai Plain of China. Agric Ecosyst Environ 114:195-209

UNFCC (United Nations Framework Convention on Climate Change) (2007) Climate change: impacts, vulnerabilities and adaptation in developing countries. http://unfccc.int/ resource/docs/publications/impacts.pdf (accessed 12 November 2010)

Wassmann R (2007) Coping with climate change. International Rice Research Institute, Manila. http://beta.irri.org/news/ images/stories/ricetoday/6-3/feature_coping \% 20with \% 20climate\%20change.pdf (accessed 12 November 2010)

Wassmann R, Dobermann A (2006) Climate change and rice cropping systems: potential adaptation and mitigation strategies. International Rice Research Institute, Metro Manila

Wilk J, Wittgren HB (2009) Adapting water management to climate change. Swedish Water House Policy Brief No. 7 , Stockholm International Water Institute, Stockholm

Submitted: July 6, 2009; Accepted: November 25, 2010

Proofs received from author(s): February 6, 2011 